\title{
岩石の非弾性ひずみ回復を用いた 三次元地圧計測法の理論的検討*
}

松 木 浩 二1

[UDC 624.121]

\section{Theoretical Examination of the Method for Measuring Three-dimensional In-situ Stresses with Anelastic Strain Recovery of Rock}

by Koji MATSUKI ${ }^{1}$

1. Faculty of Engineering, Tohoku University, Aoba-ku, Sendai 980

\begin{abstract}
Anelastic strain recovery method is one of inexpensive and simpler methods for measuring in-situ stresses at great depth. However, the method has been based on the critical assumptions that the vertical boring axis is one of principal directions and that vertical stress is given by overburden pressure, which are not always true for actual rock masses.

In this study, by deriving a fundamental equation on the anelastic strain recovery of isotropic visco-elastic material in general three dimensional stress state, the method for measuring three-dimensional in-situ stresses has been proposed. In the method, by measuring six independent anelastic normal strains of a core, six anelastic strain deviations and anelastic volumetric strain are determined first. From the former, the orientations of principal in-situ stresses and ratios of principal in-situ stress deviations are determined without the knowledge of anelastic strain recovery compliances of the core, in-situ pore pressure and temperature change in the core. Then, by evaluating pore pressure and by correcting the effect of temperature change on the anelastic volumetric strain, absolute three dimensional in-situ stresses are determined by measuring the anelastic strain recovery compliances of the rock core in both shear and volumetric modes in the laboratory.
\end{abstract}

KEY WORDS: Anelastic Strain Recovery, In-situ Stress Measurement, Three-dimensional Stresses, Visco-elastic Model

1. 緒 言

石油開発や地熱開発で行われる水王破研を用いた地下き裂の作

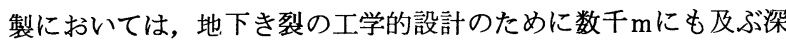
度における地王状態を正確に把握することが必要になる。これま でに, 応力解放法を主体として種々の地王計測法が提案され, ま た実際に用いられているが，これらのなかで地下深部に適用でき るものは限られており, 現在水圧破砕法が最も有力であると考元 られる。しかし, 水圧破砕法は計測深度が大きくなるに伴って費 用がかさむことや地温が高い場合には適用できないなどの問題が あり，とくに地熱開発の分野で水王破砕法に代わり得る簡便な深 部地王計測法の開発が求められている。このため, 近年, ボーリ ングコアを用いた方法が注目されている。これには, AEのカイザ 一効果を利用したもの $(\mathrm{AE} \text { 法 })^{1)}$, クラック密度の計測によるも の (DSA法 $)^{2)}$, 非弾性ひずみ回復を用いたもの (Anelastic strain recovery 法: 以後ASR法と呼ぶ ${ }^{3)}{ }^{4)}$, 変形率の変化を 用いたもの ${ }^{5)}$ などが挙げられる。しかし, これらの方法は, その 基礎となるメカニズムや原理が必ずしも十分に実証されていない

* 1991 年 6 月 5 日受付 8 月 6 日受理

1. 正会員 工博 東北大学助教授 工学部資源工学科

キーワード : 非弾性ひずみ回復, 地圧計測, 三次元地圧, 粘弾性モデル
こと, 岩石の挙動の正確な理解に基づいていないこと, また岩種 に対する適用性が十分明らかではないことなどから，計測結果に 対する信頼性は必ずしも高くないのが現状である。しかし，これ らの方法は簡便でかつ低コストであり，その信頼性を高めること ができれば, 石油や地熱開発の分野のみならず地下構造物の安定 設計など地下工学にかかわる幅広い分野に応用が可能であり, そ の意義も大きいと考えられる。

ボーリングコアを用いたこれらの方法はそれぞれの開発段階に あると言えるが, AE法やDSA法では，一応，三次元地圧または その比が計測されるのに対して,これまでのASR法では, 鉛直な ボーリング軸方向が主応力方向でかつそれが被り压で与えられる と仮定している ${ }^{3) 4)}$ 。これまでの多くの地王計測結果 ${ }^{6)}$ によれば, この仮定が多くの場合正しくないことが知られており，従って， この仮定から求めた計測結果は著しく信頼性の低い結果を与える と言わざるを得ない。また, 従来のASR 法では, 実際の岩石の非 弾性びずみ回復特性に関する研究がほとんどないまま, 岩石の時 間依存的変形挙動が応力の大きさに比例すると仮定している。し かし, クリープ変形に関する従来の研究 ${ }^{7)}$ が岩石の粘弾性的定数 の応力依存性を明らかにしており，非弾性ひずみ回復特性の応力 依存性についても検討の余地があることを示唆している。

このように,これまでのASR 法を信頼できる地圧計測法に発展 させるためには検討しなければならない多くの課題がある。なか 


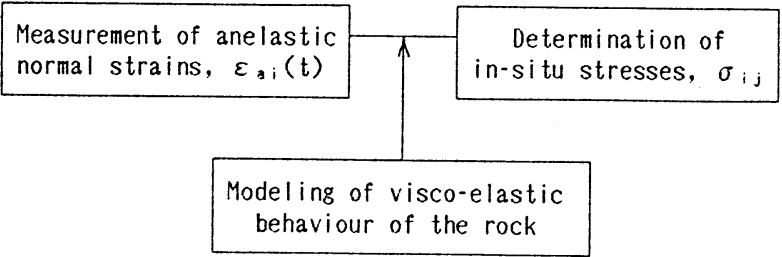

Fig. 1 Scheme of anelastic strain recovery method for measuring in-situ stresses.

でも, 主応力の一つが鉛直でかつ被り圧で与えられるという仮定 を設けることなく，測定結果から直接三次元的な地圧を決定する 方法を開発することは最も重要な課題である。本研究では, ASR 法による三次元地压計測法を開発することを目的として，まず一 般的な三次元応力状態の等方粘弾性体におけるひずみ回復に関す る理論的考察を行い, 次に, それに基づいて三次元地王計測法の 提案を行う。

\section{A S R 法の基本原理および従来の研究}

岩石に長時間一定の応力を加えた後除荷すると, 瞬間的な弾性 ひずみの解放後にも岩種によっては数日間もひずみの回復が続 く ${ }^{8)}$ 。同一岩石であれば，それまでに加わっていた応力が大きい ほどこの非弾性ひずみの回復量も大きい。従って，地下から採取 されたボーリングュアについて非弾性回復ひずみを計測すれば地 圧に関する情報が得られる。しかし，地圧を定量的に把握するた めには，岩石の非弾性ひずみ回復特性を定量的に評価する必要が あり, このため, これまでの研究では岩石を等方線形粘弾性体で あると仮定している。

図 1 は, ASR法による地王計測の基本骨格を示したものである。 まず，非弾性回復ひずみを種々の方向について計測する。従来の 研究では, コア軸方向および 3 つの半径方向の計 4 方向の非弾性 びずみを計測している。次に，岩石の粘弾性挙動のモデル化を通 じて得られる単位解放応力当たりの非弾性回復びずみの時間変化 である非弾性ひずみ回復コンプライアンスから地圧と非弾性ひず み回復量の関係を定め,これにより地王を求める。

Blanton ${ }^{4)}$ やWarpinski ら ${ }^{8)}$ は, 鉛直ボーリングによって得ら れるコアの非弾性回復ひずみについて，既に述べたように，鉛直 方向が一つの主応力軸でありかつその主応力が被り压で与えられ ると仮定して水平面内の地压成分を求めている。Blanton ${ }^{4)}$ は, ポアッソン比が時間依存性を有せず, 岩石の粘弾性挙動が一つの ひずみ回復コンプライアンスで記述されると仮定することにより， 岩石の非弾性ひずみ回復特性を知ることなしに，任意の時間間隔 における非弾性ひずみ回復量から水平面内の最大および最小主応 力を求める方法を提案している。しかし, これは, Warpinski ら ${ }^{8)}$ が批判しているように, 岩石の粘弾性挙動を正確に考慮している とは言い難い仮定である。一方, Warpinski ら ${ }^{8)}$ は, 岩石を図 2 で 表される 3 要素の線形粘弾性モデルで表し, 体積変形とせん断変 形に関する非弾性ひずみ回復コンプライアンスを用いて水平面内 の非弾性ひずみを定式化し，せん断変形に関する非弾性ひずみ回 復コンプライアンスの係数 $J_{1}$ か水平最小主応力 $\sigma_{3}$ のどちらかを 与えることにより最大水平主応力を求める方法を提案している。 そして, 例えば水圧破砕法によって求められた水平最小主応力 $\sigma_{3}$ を用いて最大水平主応力を決定している。

\section{3. 等方粘弾性体における非弾性回復ひずみ}

本章では，ASR 法による 地王計測の理論的基礎を確立するた めに, 三次元応力状態にある等方粘弾性体の応力がステップ状に

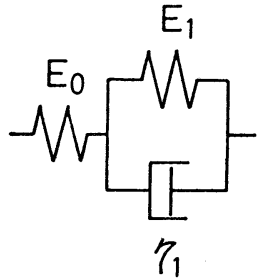

\section{three-element model}

Fig. 2 A linear visco-elastic model for anelastic strain recovery of rocks.

解放された場合の任意の方向の非弾性垂直ひずみについて考察す る。

まず，等方粘弾性体としての岩石のラプラス変換後の構成則が, せん断変形と体積変形という2つの変形モードで表され, 偏差応 力 $S_{i j}$-偏差ひずみ $e_{i j}$ 関係および平均垂直応力 $\sigma_{m}$ - 平均垂直 ひずみ $\boldsymbol{e}_{m}$ 関係について次の式で与えられると仮定する ${ }^{9 ｝ \text { 。 }$

$P_{S}(s) \overline{S_{i j}}=Q_{S}(s) \overline{e_{i j}}$,

$P_{V}(s) \overline{\sigma_{m}}=Q_{S}(s) \overline{e_{m}}$

ただし, $P, Q$ は, $s$ の関数であり, 線形粘弾性体の場合は $s$ 多 項式である。また,下付きの添字 $s, v$ は, それぞれ, せん断変形 および体積変形に関するものであることを表し, $\overline{S_{i j}}$ などは, $S_{i j}$ などをラプラス変換したものである。(1)式は，等方粘弾性体の三 次元的な構成則を与える。このような粘弾性体の応力がステップ 状に解放された場合の単位応力当たりのひずみの時間変化ーびず み回復コンプライアンスーは，(1)式より，せん断変形 $J_{S}$ および 体積変形 $J_{V}$ について，それぞれ次式で表される。

$$
\overline{e_{i j}} / S_{i j}=\overline{J_{S}(s)}=P_{S}(s) /\left(Q_{S}(s) s\right) \text {, }
$$$$
\overline{e_{m}} / \sigma_{m}=\overline{J_{V}(s)}=P_{V}(s) /\left(Q_{V}(s) s\right)
$$
ただし， $S_{i j}, \sigma_{m}$ は解放以前に加わっていた応力である。なお, 岩石をある粘弾性モデルで表せば，ひずみ回復コンプライアンス はいわゆるクリープコンプライアンスの符号を変えたものと一致 する。しかし，クリープュンプライアンスには，いわゆる三次段 階が含まれることがあるのに対して，びずみ回復コンプライアン スは必ず一定值に収束すると考えられるように, 現実の岩石では 応力レベルによってそれらが異なる可能性もあり, 本研究では, ひずみ回復挙動をクリープ挙動と区別して扱う。

次に，(2)式は瞬間的に解放される弾性ひずみも含んでいるので, 全ひすずみ回復コンプライアンスから弾性ひずみを除いたそれぞれ

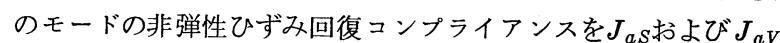
で表す。すなわち, 時間を $t$ で表すと,

$$
J_{a S}(t)=J_{S}(t)-J_{S}(0), J_{a V}(t)=J_{V}(t)-J_{V}(0)
$$

なお, 従来の研究で用いられている 3 要素モデル (図 2 ) から得 られる非弾性ひずみ回復コンプライアンスは次式で与えられる。

$$
J_{a}(t)=\left(1 / E_{1}\right)\left\{1-\exp \left(-t / \lambda_{1}\right)\right\}
$$

ただし, せん断変形と体積変形に関するものは上式の定数が異な るだけで式の形は同じであり, $\lambda_{1}\left(=\eta_{1} / E_{1}\right)$ は遅延時間である。 なお, $\eta_{1}$ と $E_{1}$ は, それぞれ, 図 2 のVoigt物体の粘性率とヤング 率である。

今, 三次元地王と間隙水圧を受けているある点 $\mathrm{O}$ の方向余弦が $(l, m, n)$ である方向の垂直ひずみ $\varepsilon$ は (図3参照), 等方弾性 体の場合，ひずみの変換式 ${ }^{10)}$ ならびに間隙水圧を考慮した Hooke の法則 ${ }^{11)}$ から，次式で表される。

$$
\begin{aligned}
\varepsilon= & (1 / E)\left(l^{2} \sigma_{x}+m^{2} \sigma_{y}+n^{2} \sigma_{z}+2 l m \tau_{x y}+2 m n \tau_{y z}\right. \\
& \left.+2 n l \tau_{z x}\right)-(\nu / E)\left\{\left(m^{2}+n^{2}\right) \sigma_{x}+\left(n^{2}+l^{2}\right) \sigma_{y}\right. \\
& \left.+\left(l^{2}+m^{2}\right) \sigma_{z}-2 l m \tau_{x y}-2 m n \tau_{y z}-2 n l \tau_{z x}\right\}
\end{aligned}
$$




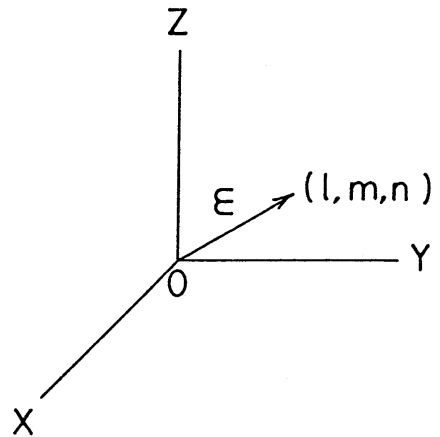

Fig. 3 Normal strain in an arbitrary direction in a visco-elastic body.

$-(1 / 3)\left(1 / K-1 / K_{S}\right) p_{o}-\alpha \Delta T$

ただし,ここでは王縮を正としており，Eはヤング率，ンはポアッ ソン比, $K$ は見掛けの体積弾性率, $K_{S}$ は岩石実質部の体積弾性率, $\alpha$ は線膨張係数, $p_{o}, \Delta T$ はそれぞれ, 間隙水圧と温度上昇である。 なお, 右辺第 3 項は, 間隙水王 $\boldsymbol{p}_{0}$ によるある方向の膨張ひずみが, 重ね合せの原理から， $p_{0}$ と等しい静水圧によって生ずる圧縮ひず み $\left(p_{o} / 3 K\right)$ と $p_{0}$ ならびにそれに等しい静水殴による王縮ひずみ $\left(p_{o} / 3 K_{S}\right)$ との差で与えられることによる。また, ここでは, 点 Oが一様な温度場にあると仮定している。

粘弾性体の場合のひずみは, 上式をラプラス変換した後, 対応 原理 ${ }^{9)}$ を用いて,

$$
\begin{aligned}
& 3 K \rightarrow Q_{V} / P_{V}, E \rightarrow 3 Q_{S} Q_{V} /\left(2 P_{S} Q_{V}+Q_{S} P_{V}\right), \\
& \nu \rightarrow\left(P_{S} Q_{V}-Q_{S} P_{V}\right) /\left(2 P_{S} Q_{V}+Q_{S} P_{V}\right)
\end{aligned}
$$

なる置き換えを行うことにより，次のように求められる。

$$
\begin{aligned}
& \overline{\varepsilon(s)}=\left(2 P_{S} / 3 Q_{S}+P_{V} / 3 Q_{V}\right)\left(l^{2} \overline{\boldsymbol{\sigma}}_{x}+m^{2} \overline{\boldsymbol{\sigma}}_{y}+n^{2} \overline{\boldsymbol{\sigma}}_{z}+2 l m \bar{\tau}_{x y}\right. \\
& \left.+2 m n \bar{\tau}_{y z}+2 n l \bar{\tau}_{z x}\right)-\left(P_{S} / 3 Q_{S}-P_{V} / 3 Q_{V}\right)\left\{\left(m^{2}\right.\right. \\
& \left.+n^{2}\right) \overline{\sigma_{x}}+\left(n^{2}+l^{2}\right) \bar{\sigma}_{y}+\left(l^{2}+m^{2}\right) \overline{\boldsymbol{\sigma}}_{z}-2 l m \bar{\tau}_{x y} \\
& \left.-2 m n \bar{\tau}_{y z}-2 n l \bar{\tau}_{z x}\right\}-(1 / 3)\left(3 P_{V} / Q_{V}-1 / K_{S}\right) \bar{p}_{o} \\
& -\alpha \overline{\Delta T}
\end{aligned}
$$

ただし, Warpinskiら ${ }^{8)}$ と同様, 実質部の体積弾性率 $K_{S}$ は時間依 存性がないと仮定している。応力と間隙水圧がステップ状に解放 された場合の粘弾性体の非弾性垂直ひずみは, $\overline{\sigma_{x}}=\sigma_{x} / s, \bar{p}_{0}=p_{0}$ /sなどを(7)式に代入した後，(2)式を用いて逆ラプラス変換する ことにより次式で与えられ，これがASR法による地圧計測のため の基礎式となる。なお,この場合のひずみは, 膨張が正である。

$$
\begin{aligned}
\varepsilon_{a}(t)= & (1 / 3)\left[\left(3 l^{2}-1\right) \sigma_{x}+\left(3 m^{2}-1\right) \sigma_{y}+\left(3 n^{2}-1\right) \sigma_{z}\right. \\
& \left.+6 l \mathrm{~m} \tau_{x y}+6 \mathrm{mn} \tau_{y z}+6 \mathrm{n} l \tau_{z x}\right] J_{a S}(t) \\
& +\left(\sigma_{m}-p_{0}\right) J_{a V}(t)+\alpha \Delta T(t)
\end{aligned}
$$

すなわち, 等方粘弾性体の応力と間隙水圧がステップ状に解放さ れた場合のある方向の非弾性垂直ひずみは, 地圧 6 成分と間隙水 王およびせん断変形と体積変形に関する非弾性びずみ回復コンプ ライアンス, さらには応力が解放された後の岩石コアの温度変化 に依存して決まる。

\section{A S R 法による三次元地圧計測法の提案}

既に述べたように, 従来のASR法では, 被り圧で与えられる鉛 直応力が一つの主応力であると仮定している。これは, 従来の方 法 $^{334) 8) 12)}$ では, 4 方向の垂直ひずみしか計測していないことに よる。すなわち，少なくとも6 個の互いに独立な垂直ひずみを計 測しなければ岩石コアの非弾性ひずみ 6 成分を一義的に決定でき ないことから，地圧に関する何等かの仮定を設ける必要が生ずる わけである。従って，ASR法を用いて完全な三次元地圧を決定す るためには，測定により少なくとも非弾性ひずみ 6 成分を決定す (a)

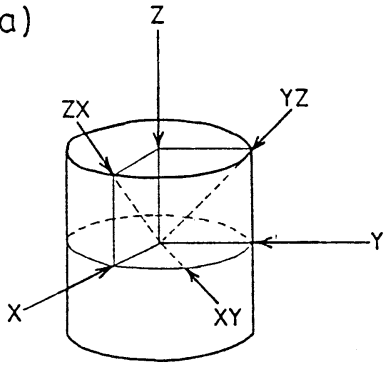

(b)

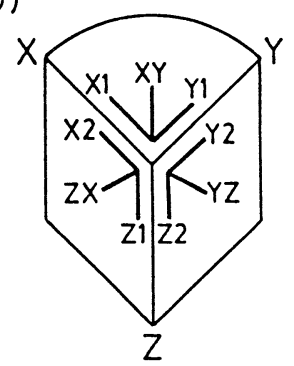

Fig. 4 Normal strains to be measured for determining threedimensional in-situ stresses with ASR method by using (a) displacement transducers or (b) strain gauges.

\section{る必要がある。}

地下から採取された岩石コアの非弾性ひずみを一義的に決定す るためには，例えば，図4(a)の矢印で示すような 6 方向について 垂直変位を測定すればよい。また, DSA 法 ${ }^{2)}$ と同様に, 口ゼット ゲージを用いて測定することも考えられる (図 4(b))。ひずみ測 定の信頼性を高めるためには, より多くの方についてより多く のひずみを測定して最小自乗法などを用いることが望ましいが， たと多くの方向について測定したとしても, 非弾性ひずみ 6 成 分以上の情報は得られない。

(8)式より，例えば図 4 (a)に示した 6 方向の非弾性垂直ひずみと 地圧は次の関係にある。

$$
\begin{aligned}
& \varepsilon_{x}=\left(\sigma_{x}-\sigma_{m}\right) J_{a S}(t)+\left(\sigma_{m}-p_{0}\right) J_{a V}(t)+\alpha \Delta T(t) \\
& \varepsilon_{y}=\left(\sigma_{y}-\sigma_{m}\right) J_{a S}(t)+\left(\sigma_{m}-p_{0}\right) J_{a V}(t)+\alpha \Delta T(t) \\
& \varepsilon_{z}=\left(\sigma_{z}-\sigma_{m}\right) J_{a S}(t)+\left(\sigma_{m}-p_{0}\right) J_{a V}(t)+\alpha \Delta T(t) \\
& \varepsilon_{x y}=\left\{\tau_{x y}-0.5\left(\sigma_{z}-\sigma_{m}\right)\right\} J_{a S}(t)+\left(\sigma_{m}-p_{0}\right) J_{a V}(t)+\alpha \Delta T(t) \\
& \varepsilon_{y z}=\left\{\tau_{y z}-0.5\left(\sigma_{x}-\sigma_{m}\right)\right\} J_{a S}(t)+\left(\sigma_{m}-p_{0}\right) J_{a V}(t)+\alpha \Delta T(t) \\
& \varepsilon_{z x}=\left\{\tau_{z x}-0.5\left(\sigma_{y}-\sigma_{m}\right)\right\} J_{a S}(t)+\left(\sigma_{m}-p_{0}\right) J_{a V}(t)+\alpha \Delta T(t)
\end{aligned}
$$

これらの非弾性垂直ひずみから，次式などを用いて非弾性せん断 ひずみ(テンソルひずみ) が求められる。

$$
e_{x y}=\varepsilon_{x y}-0.5\left(\varepsilon_{x}+\varepsilon_{y}\right)
$$

従って, 岩石ュアのひずみ回復に伴う非弾性びずみ 6 成分は, 次 のように表される。

$$
\begin{aligned}
& \varepsilon_{x}=\left(\sigma_{x}-\sigma_{m}\right) J_{a S}(t)+\left(\sigma_{m}-p_{0}\right) J_{a V}(t)+\alpha \Delta T(t) \\
& \varepsilon_{y}=\left(\sigma_{y}-\sigma_{m}\right) J_{a S}(t)+\left(\sigma_{m}-p_{0}\right) J_{a V}(t)+\alpha \Delta T(t) \\
& \varepsilon_{z}=\left(\sigma_{z}-\sigma_{m}\right) J_{a S}(t)+\left(\sigma_{m}-p_{0}\right) J_{a V}(t)+\alpha \Delta T(t) \\
& \boldsymbol{e}_{x y}=\tau_{x y} J_{a S}(t) \\
& \boldsymbol{e}_{y z}=\tau_{y z} J_{a S}(t) \\
& \boldsymbol{e}_{z x}=\tau_{z x} J_{a S}(t)
\end{aligned}
$$

ただし, 時間 $t$ は応力解放後の経過時間である。ここで, 上式か ら求められる平均垂直ひずみ $e_{m}$,

$$
e_{m}=\left(\sigma_{m}-p_{0}\right) J_{a V}(t)+\alpha \Delta T(t)
$$

を用いて偏差ひずみ $e_{x}$ 等を求めると, これらは偏差応力 $s_{x}$ 等と 次の関係にある。

$$
\begin{aligned}
& e_{x}=s_{x} J_{a S}(t), e_{y}=s_{y} J_{a S}(t), e_{z}=s_{z} J_{a S}(t) \\
& e_{x y}=\tau_{x y} J_{a S}(t), e_{y z}=\tau_{y z} J_{a S}(t), e_{z x}=\tau_{z x} J_{a S}(t)
\end{aligned}
$$

(13)式から次のことがわかる。すなわち，各偏差ひずみが，対応す る偏羑応力とせん断变形に関する非弾性ひずみ回復コンプライア ンスの積で表されることから，任意の時刻における偏差ひずみの 主軸の方向は一定でかつ偏差応力の主軸の方向と一致する。従っ

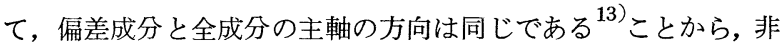
弾性主ひずみの方向は時刻にかかわらず一定でかつ主応力の方向 
を与える。さらに，任意の時刻における偏差ひずみの比を求めれ ば，当該岩石の非弾性びずみ回復特性を知ることなしに，地圧の 偏差成分の比が求められる。また，偏差ひずみは岩石試料内で一 様な温度変化の影響を受けないので, 温度が試料内で一様であれ ば，試料の温度が変化してもこれらのことは成り立つ。上記のこ

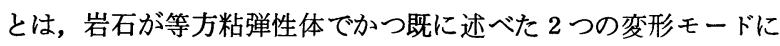
よって三次元的な変形挙動が支配されるという仮定から導かれる 当然の帰結である。従って, 逆に, 非弾性主ひずみの方向と偏差 ひずみの比が時間にかかわらず一定であるかどうかをチェックす ることにより，用いた仮定が当該岩石に対して正しいかどうか吟 味することができる。

これらの偏差ひずみから，ある時刻 $t$ における偏差主びずみ $e_{i}(i=1,2,3)$ を求めれば, (13)式より, これは偏差主応力 $s_{i}$ と 次の関係にある。

$$
s_{i}=e_{i}(t) / J_{a S}(t)
$$

従って, 主応力 $\sigma_{i}$ は, 上式および(12式より，次式で与えられる。

$$
\begin{aligned}
\sigma_{i} & =\sigma_{m}+e_{i}(t) / J_{a S}(t) \\
& =e_{i}(t) / J_{a S}(t)+\left\{e_{m}(t)-\alpha \Delta T(t)\right\} / J_{a V}(t)+p_{0} \cdots \text { (15) }
\end{aligned}
$$

すなわち, 岩石の非弾性回復ひずみの測定から 3 次元の主応力を 決定するためには，まず第 1 に平均垂直ひずみに及ぼす温度変化 の影響の正確な補正と間隙水王の評価が必要であり,さらに当該 試料のせん断変形ならびに体積変形に関する非弾性びずみ回復 ンプライアンスを知る必要がある。これらのうち, 温度変化の影 響は計測深度が大きいほど問題となるが，非弾性びずみとともに 試料の温度を測定しておけば，びずみ回復が完全に終了した後に 当該試料を用いて線膨張係数を測定することにより補正できる。 また, 通常, 測定は䨌囲気温度を一定に保った状態で行うため, 非弾性ひずみ回復量が大きくてかつ十分長く続く場合には, 温度変 化の影響が生じる初期のデータを無視することでも解決可能であ る。間隙水王は検層等により測定または評価できる。非弾性びず み回復コンプライアンスは，計測に供した試料と同じュアを用い $\tau$, 例えば三軸圧縮応力下で十分長い時間一定応力 $\sigma_{1}, \sigma_{3}$ を保 持して応力を解放した後に生ずる軸方向および横方向の非弾性ひ ずみ $\left(\varepsilon_{1 a}, \varepsilon_{3 a}\right)$ を実験室で測定することにより, 次式から求め ることができる。

$$
\begin{aligned}
& J_{a V}(t)=\left\{\varepsilon_{1 a}(t)+2 \varepsilon_{3 a}(t)\right\} /\left(\sigma_{1}+2 \sigma_{3}\right) \\
& J_{a S}(t)=\left\{\varepsilon_{1 a}(t)-\varepsilon_{3 a}(t)\right\} /\left(\sigma_{1}-\sigma_{3}\right)
\end{aligned}
$$

なお, 測定中の水分変化の影響を除くために, 通常, 測定は試料 を被覆してから行うので, 被覆材として耐圧性のものを選択する ことにより，非弾性ひずみの測定終了後に当該試料を用いて，一 定時間静水圧を加えて除荷することにより体積変形に関する非弾 性ひずみ回復コンプライアンスを直接求めることが可能である。 ただし，既に述べたように， $J_{a V}$ や $J_{a S}$ に応力依存性があると考 えられることから, 実験室でこれらを求める際に用いる応力の大 きさには注意を要する。すなわち，できるだけ実際の地圧に近い 値を用いることが望ましい。この点からの $J_{a V}$ や $J_{a S}$ の正確な評 価法の確立は今後の研究課題であるが，例えば，鉛直応力を被り 压と仮定して求められる地圧の近似值を用いることが考えられる。 このように，岩石の非弾性ひずみと非弾性びずみ回復コンプライ アンスの測定により三次元的地王の大きさが決定される。

ところで，これまでは応力解放後の時間を問題にしてきた。し かし，実際には，地下の岩石がボーリングによって応力解放を受 けた後地上に上がってくるまでにはかなりの時間がかかる。図 5 は, 応力が解放されてから時間 $t_{0}$ が経過した後に測定を開始し た場合の非弾性ひずみ回復コンプライフンスへの影響を模式的に 示したものである。応力解放後の経過時間が長いほど非弾性ひず

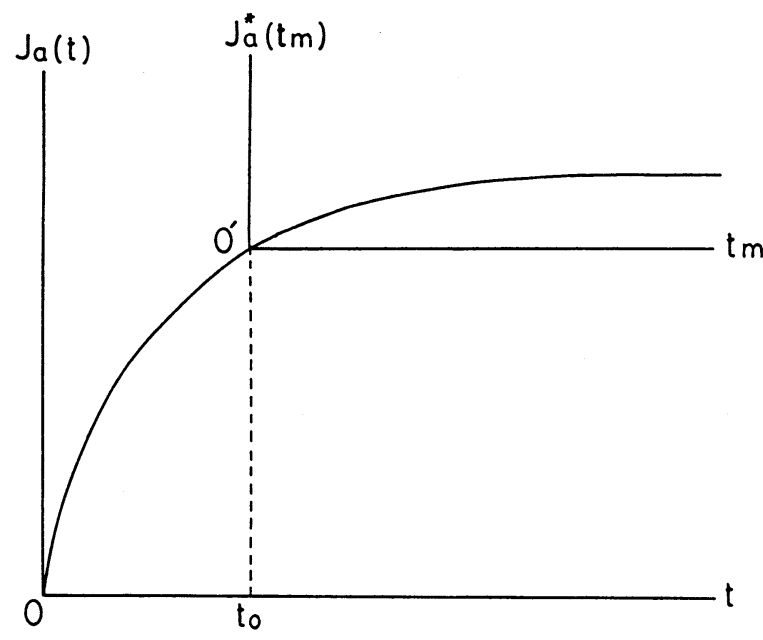

Fig. 5 Effect of elapsed time on the evaluation of anelastic strain recovery compliances.

み回復コンプライアンスの後半部分しか現れないので測定される 非弾性ひずみも小さくなる。測定開始からの経過時間を $t_{m}$, そ れに対応する非弾性ひずみ回復コンプライアンスを $J_{a}^{*}\left(t_{m}\right)$ とお けば,

$$
J_{a}^{*}\left(t_{m}\right)=J_{a}\left(t_{0}+t_{m}\right)-J_{a}\left(t_{0}\right)
$$

である。従って,これまでの式中の非弾性ひずみ回復コンプライ アンス $J_{a}$ の代わりに $J_{a}^{*}$ を, また時間 $t$ の代わりに $t_{m}$ を用いれ ば，これまでのことがそのまま成り立つ。すなわち，岩石の非弾 性ひずみ回復コンプライナンスがあたかも $J_{a}^{*}\left(t_{m}\right)$ であるかのよ うに扱えばよい。このように，測定開始の時間遅れを考慮した場 合，主応力の大きさは次式で与えられる。

$$
\begin{gathered}
\sigma_{i}=e_{i}^{*}\left(t_{m}\right) / J_{a S}^{*}\left(t_{m}\right)+\left\{e_{m}^{*}\left(t_{m}\right)\right. \\
\left.-\alpha \Delta T^{*}\left(t_{m}\right)\right\} / J_{a V}^{*}\left(t_{m}\right)+p_{0}
\end{gathered}
$$

ただし, * は時刻 $t_{0}$ 以後の変化量を表す。従って, 非弾性ひずみ 回復コンプライアンスとして実験室で求められる $J_{a}$ のうち $t=t_{0}$ 以後の值を用いれば，(18)式から主応力を求めることができる。な お，既に述べたように，主応力の方向の評価には計測開始時刻の 影響はない。

このような手順で三次元的地压の方向と大きさを求めれば，岩 石の粘弾性的変形挙動を特定の力学的モデルで表す必要はないが, 種々の岩石の非弾性ひずみ回復挙動を比較したり, また通常の力 学的試験から求められる物性值から岩石の非弾性ひずみ回復コン プライアンスを推定したりする上では有効である。ちなみに，図 2 に示した 3 要素モデルの場合, $J_{a}^{*}\left(t_{m}\right)$ は次式で表される。

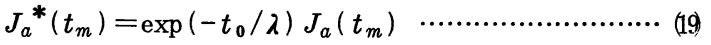
すなわち, 当該岩石の遅延時間 $\lambda$ と測定開始時刻 $t_{0}$ との関係で $J_{a}^{*}$ の $J_{a}$ に対する低下率が決まる。

本研究で提案した A SR 法による三次元地压の計測手順をまと めて図6に示した。同図に示した計測手順は, 主として地熱開発へ の応用を意識したものであるが, 岩石コアの温度変化が無視でき る場合にはより簡便に精度のよい三次元地王計測が可能である。

\section{5. 結言}

本研究では, ボーリングュアを用いた地圧計測法の一つである 非弾性ひずみ回復法（ASR法）に注目し，より一般的な三次元地 王状態における等方粘弾性体についての任意の方向の非弾性垂直 ひずみについて考察することにより，同方法を三次元地厈計測法 


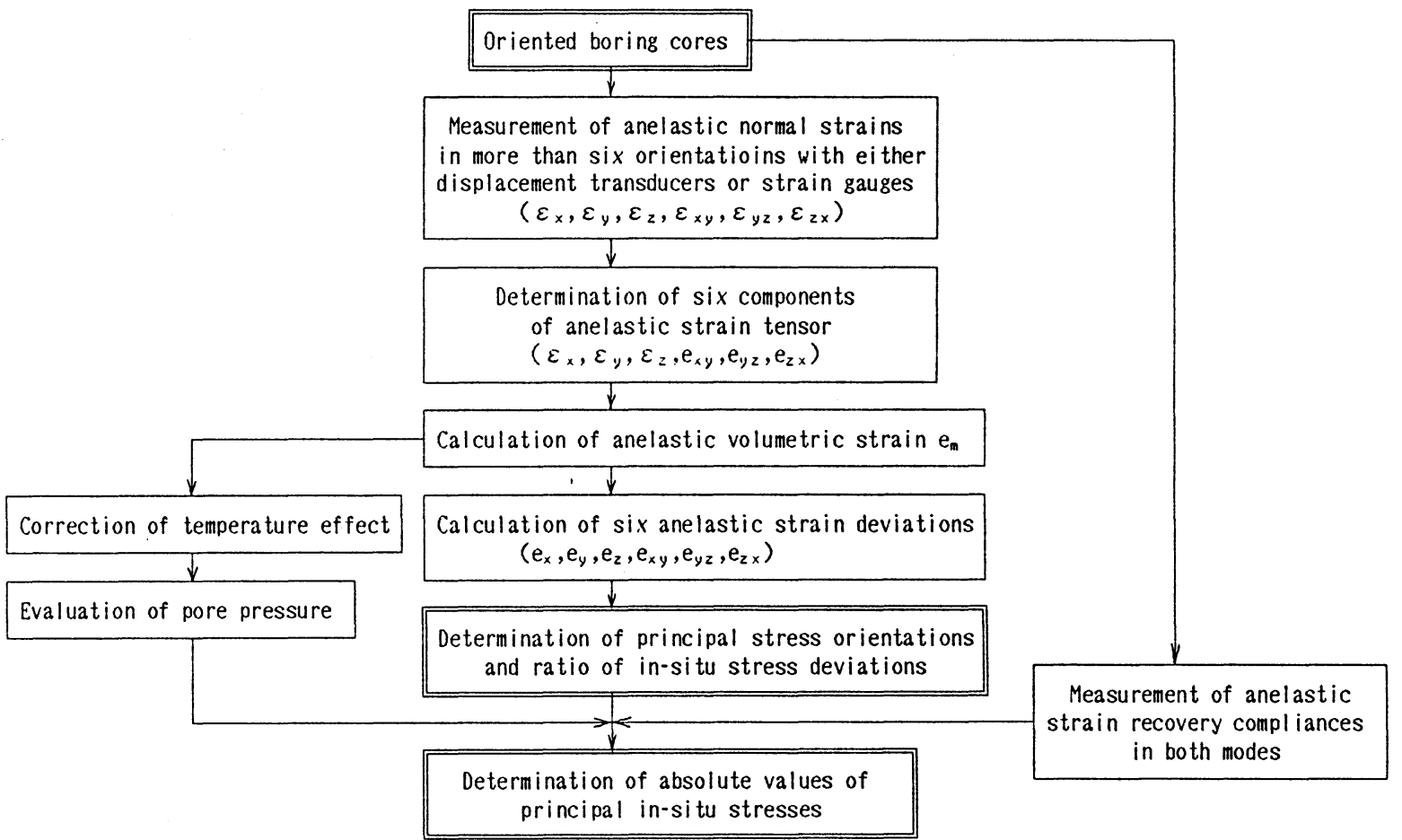

Fig. 6 The procedure for determining three dimensional in-situ stresses from anelastic strain recovery of an oriented core.

として拡張する方法について提案し，また実際の計測手順を示し た。本方法は, まだ開発の初期段階にある。三次元地王計測法と しての ASR 法を真に信頼性のある方法にするためには, 岩石の 非弾性ひずみ回復コンプライフンスの応力依存性の検討, 岩種に よる非弾性ひずみ回復特性の差異の評価と ASR 法の適用性判定 法の開発, 岩石の力学的異方性の影響の評価, さらには高精度の 長期ひずみ計測法の開発等, 多くの問題が残されている。しかし, 岩種によっては，これまで不可能であった地下深部の地圧計測が 経済的かつ簡便に行える方法であり，今後有力な方法となると期 待される。

本研究を遂行するに当たり, 東北大学工学部の鈴木舜一, 高橋 秀明ならびに阿部博之教授から貴重なご教示を賜った。また，本 研究は文部省科学研究費 (一般 C ) ならびに民間等との共同研究 費によった。記して感謝申し上げる。

\section{参考 文 献}

1) 金川 忠ほか : 第 7 回岩の力学国内シンポジウム講演論文集, 193 $\sim 198$, (1987)

2) Strickland, F.G. et al.: Proc. 21st U.S. Sympo. on
Rock Mech., 523 532, (1980)

3) Teufe1, L. W. : Proc. 23 rd U.S. Sympo. on Rock Mech., 238 245, (1982)

4) Blanton, T.L. et al.: SPE 11624, (1983)

5) Yamamoto, K. et al.: Tohoku Geophysical Journal, 33 [2], 127 147, (1990)

6) Brown, E. T. et al. : Int. J. Rock Mech. Min. Sci., 15, $211 \sim 215,(1978)$

7）山口 勉ほか：日鉱誌, $100[1158], 631 \sim 635,(1984)$

8) Warpinski, N. R. et al.: J. Petr. Tech., 405 414, (1989)

9) Flugge, W.: Visco-elast icity, 176 178, (1967), Blaisdell Pub. Co., Wal tham

10) J aege r , J. C. : 弾性・破壊・流動論（飯田汲事訳），48～52, (1968), 共立出版

11) Jaeger, J. C. and Cook, N.G.W. : Fundamentals of Rock Mechanics, 211 214, (1976), John Wiley \& Sons, Inc.

12) Wolter, K. E. et al.: Rock Mech. and Rock Engng., 22, 273 287, (1989)

13) Jaeger, J. C. and Cook, N. G. W. : Fundamentals of Rock Mechanics, 32 33, (1976), John Wiley \& Sons, Inc. 